УДК 398

https://doi.org/10.18485/godisnjak.2021.16.5

Драгана Б. Вукићевић*

Универзитет у Београду

Филолошки факултет
Оригинални научни рад

Примљен: 15. 09. 2021.

Прихваћен: 05. 11. 2021.

\title{
ГРАНИЦА: МРТВИ ЖИВИ
}

У раду се проучавају различити начини концептуализације иреверзибилне границе између света живих и света мртвих. Студија је сегмент ширих проучавања тромплејских бића, оних која су онтолошки бивалентна, зазорљива и непреводива у свет могућих искустава и говора.

Кључне речи: вампир, граница, обред прелаза, наратив, тромплејска бића.

Савремена вампирологија, сходно интердисциплинарности на којој почива, понудила је различите начине концептуализације границе: један је везан за етнолошке студије (етнолошко декодирање граничних простора), други за имаголошке (опасност од суседа), трећи за медицинско-психолошку границу између нормалног стања и лудила, четврти, за науку о књижевности (проблем когнитивних оквира, алтернативних светова, онтолошких крајолика). Будући да је прелазак иреверзибилне границе суштинско идентитетско обележје тромплејских, онтолошки бивалентних бића, у наредним поглављима навешћемо неколико примера различитих когнитивних перспектива које их творе.

Излазак из гроба - представља прво кршење табуа и прву границу коју прелази сваки вампир. Ово повлачи са собом потпуно нову семантизацију јунака за које више не важи каузалности, нити миметичке поредбе да су

”prof.vukicevic.dragana@gmail.com 
гори, бољи или попут нас: они су живи а мртви су, уместо да труну задржавају телесну свежину; они нису скелет и тело које се биолошки распада већ тело кроз које кола крв; они су покретни и могу преузети и друге атрибуте живих - могу имати сексуални нагон, комуницирати са живима, бити заводљиви и привлачни и сл... Колико год били „као живи”, њих не ствара реторика поређења - они су фигуре парадокса јер они су немогући могући: немртви, живи покојници, оживели мртваци; они су „синергија разноврсних табуа присутних у многим културама” (Холи 2019: 291, 301).

Међусветовни „онтолошки туризам” покренуо је немогућа путовања која нису нужно подразумевала кретања кроз географски простор. Границе су могле бити: А) локалне (актери приче људи који се знају - у селу, у готским причама, људи из замка), Б) границе су могле бити много веће, регионалне (актери приче опасни суседи из друге државе), В) могле су се селити у ум (граница нормалности и лудила), или Г) у причу (истиниту или лажну).

А) Будући да вампиров живот почиње изласком из гроба делокруг његовог деловања најчешће је одређен удаљеношћу од гробног места. У фолклорном контексту вампир је примарно регионална појава са специфичном локалном путањом прецизно маркираном у студијама етнолога: „У српској култури тај митски простор боравишта вампира припао је гробљу, а простор деловања јесте бивши дом, цело насеље, потом воденица, гранични делови шума, за разлику од нешто ширег европског фолклора, где се поред гробља често уводи и стари замак, дворац" (Марјановић 2012: 38).

Веселин Чајкановић, сходно месту деловања, разликује сеоске односно руралне, и урбане, племићке вампире, а као њихови типични представници одабрани су су Глишићев, односно Полодоријев вампир (Шаровић 2008: 11). ${ }^{1}$ Сеоски или градски локалитет битно је утицао на диференцијацију вампира и његову „креолизацију” са другим ликовима (нпр. са осветољубивим мужевима у фолклорним причама, кобним заводницима, блазираним аристократама, еротоманима).

Упркос популарности урбаних прича о вампирима и западноевропској трансмедијалној контекстуализацију вампира-заводника, у Србији се примарно стабилизовао наратив о сеоском вампиру.

\footnotetext{
${ }^{1}$ Марија Шаровић набраја дистинктивне црте урбаног и фолклорног вампира фокусирајући се на вампирску љубав и иницијацију, полиморфност и андрогинију. Једина константа која се не мења везана је за делокруг јунака који се храни крвљу и који припада и хтонском свету. „Његова основна дистинктивна црта јесте крвожедност” (Шаровић 2008: 11, 56).
} 


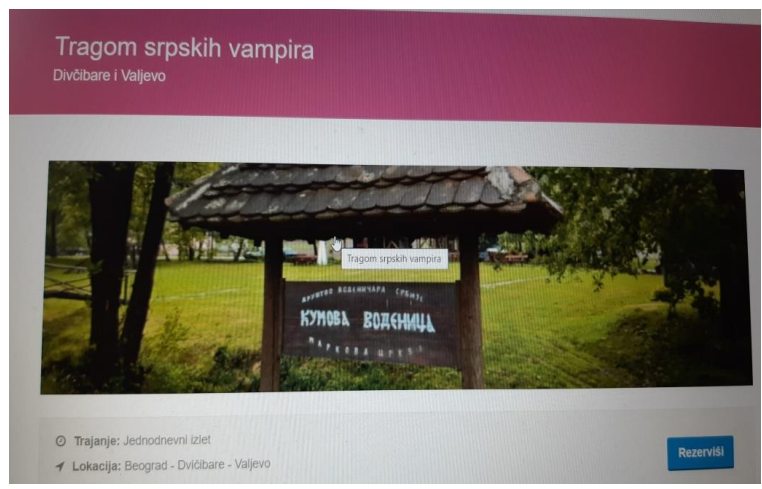

Најпознатији сеоски вампир Сава Савановић, обликован у Глишићевој приповеци После деведесет година, не само да је постао трансветовни и трансмедијални јунак који прелази границе жанрова, сели се из приповетке у роман, и границе медија (из књижевности у филм) већ je ,закорачио” и у реалан свет као главна атракција „страва туризма”2).

У савременим, нарочито западноевропским и америчким филмским транспозицијама, међутим, порекло вампира је престало да буде важно и он је постепено „губио” свој локални карактер прерастајући у општи симбол.

Б) Од локалне путање коју вампири прелазе крећући се у уском кругу познатих, други тип границе се стварао на међама царстава, у односу према другом, туђем, неразумљивом и непознатом. Индикативна је рецепција вампира који су се у 18. веку појавили у малом српском селу Медвеђа, на граници две моћне империје (Хабсбуршке и Турске). Исељавање сељана због страха од вампира тумачило се као двостука опасност: једна се односила на стабилност границе, а друга, на опасног непознатог повампиреног суседа (в. коментар М. Клеут у књизи Вампири у Србији у 18. веку). ${ }^{3}$ И док

${ }^{2}$ У оквирима савремене туризмологије развијена је посебна грана „тамни туризам” (dark tourism) окренута проучавањима садржаја везаних за просторе смрти и трагедије. У нашој интерпретацији, „страва туризам” се односи на реалне просторе који присвајају и архивирају просторе прича страве и нису повезани са реалним смртима и трагедијама. У српској туристичкој понуди опасна воденица у којој борави српски вампир Сава Савановић налази се као означено привлачно место за „страва туристе”. У опису туристичке понуде стоји: „Путовање за Ваљево и одлазак на речицу Градац, до вампирске воденице - Да ли сте знали да је реч „вампир” српског порекла? То ћемо вам показати у воденици у каквој је своју жеђ гасио први од светских вампира!!!” https://mayaktours.com/package/izlet-tragom-srpskih-vampira/

${ }^{3}$ Марија Клеут скреће пажњу на имаголошке аспекте извештаја који је „истовремено (je) сведочанство о сусрету две културе: западневропске оличене у аустријским официрима и српске представљене кроз ликове домаћег становништва.” (Клеут, 2018: 37) У поглављу 
су мештани Медвеђе мучили муку са мртвима који су излазили из земље, аустријски војни стратези са потенцијалним српским дезертерима који су бежећи од мртвих заправо слабили одбрамбену моћ Царства, у западноевропском мњењу стварала се нова граница подупирана фикцијом (особито жанром готске приче). Весна Марјановић, инспирисана Боновим чланком Вампиризам у Пруској и Аустрији, пише о метафоризацији лимитрофних области, раздвајању западне и источне културу и јачању „словенофобија царства" - Бон 2009, Марјановић 2012: 14).

Из перспективе центра моћне Хабсбуршке монархије појава вампиризма се географски ширила на сва гранична подручја са православним становништвом (Угарској, Моравска, Шлезија и Пољска $)^{4}$, а у причу су се укључивали и Грци са својим брколацима. (Лазаревић ди Ђакомо 2016: 144). Прича о „вампирском” Другом (друге вере и са опасне границе) подупирана је и (псеудо)медицинском аргументацијом, болешћу нерава и грозницом карактеристичним за словенски, а не за германски свет о чему је 1734. у делу Tractat von dem Kauen und Schmatzen der Todten in Gräbern ауторитативно писао Михаел Ранфт (Лазаревић ди Ђакомо 2016: 134).

Новоуспостављену балканску границу подупирала је још једна прича. Марија Шаровић у књизи Метаморфозе вампира: компаративна анализа мотивског комплекса вампира у делима Р. Метисона, Б. Пекића, Б. Вијана и С. Лујањенка примећује: „Обузетост Балканом постала (је) особеност готске прозе, а посебно приче о вампиру, чији историјски прототип, Влад Цепеш, долази из Трансилваније, ,земље иза шума” (Шаровић

\footnotetext{
„Представа о другом” анализирајућу страну рецепцију она пише: „Ако се занемари тешка артиљерија њихових аргументата (религиозних, здраворазумских, уз позивања и на Библију и на лабораторијски експеримент), преостаје за аспекте овог рада важан података да у свим тим списима људске крвопије обитавају негде далеко, на крајњим границама нашег (аустријског, немачког) света или долазе преко границе, међу људе који нису „ми” и који се од „нас” разликују и по необичним обичајима" (Клеут 2018: 65). Марија Клеут наводи оновремена запажања о прећуткивању појаве вампира у домаћем (немачком) простору: „Могао бих да наведем пример који се у једној немачкој провинцији десио неком из племства, који је довољно далеко од Медвеђе, а ипак је након смрти осетио скоро исти процес као и вампири; али његов род је сувише познат, поштено је да одустанем од такве приче" (Клеут 2018: 27).

${ }^{4}$ У студији Персиде Лазаревић ди Ђакомо цитирани су извештаји у којима се износе детаљно подаци о местима где су се појавили вампири, али се у духу просветитељских идеја, ти извештаји приписују неукости и сујеверју становништва. Ауторка наводи коментар издавача Јохана Хајнирха Цедлера из 46. тома Универзалног лексикона у којем се даје још једно објашњење за веровање у ствари и појаве којих нема: „Цедлер $(1747,477)$ је у свом лексикону закључио нешто што ће се не тако ретко појављивати у причама о вампирима, а то је да се ове појаве бележе међу Рацима (Rätzen), који су православне вере, јер православци верују у ђавола и сматрају да мртви могу да иду ноћу уоколо и нападају људе” (Лазаревић ди Ђакомо 2016: 132)
} 
2008: 129). ${ }^{5}$ Уз причу о влашком војводи Владу Цепашу, грофу Дракули, у вампирологији се истиче и утицај легенди о мађарској грофици Ержебет Батори, серијском убици која је пила крв жртава верујући да се тиме подмлађује (Твитчел: 1981, Шаровић: 2016). У вампиристичкој географији, оваквим причама Балкан се дефинитивно утврђивао као место Другог и опасног. Од локалних узурпатора, вампири су за кратко време постали јунаци европске штампе, скандалозних хроника, мистериозних прича, о суседима са границе. Балкански крвожедни вампир се поред Турака, разбојника, лопова, демона, увукао међу непријатеље Запада (Делимо, 1989). (О Балкану као кључној тачки вампиристичке картографији в. зборник радова индикативног наслова Liber monstrorum balcanorum - чудовишни свијет еуропске маргине, Загреб, 2019) ${ }^{6}$.

В) Паралелно са сеоском путањом вампира од гроба до познатих места где је некада боравио, паралелно са причама о опасном Другом који је на граници Државе, модерна вампиристичка проза развила је још једну, другачију - унутрашњу путању њиховог кретања. Дом вампира постао је људски ум. Сељењем демона из спољашњег света у унутрашњост ума ствара се ново сеновито подручје ${ }^{7}$, нова идеална локација за појаву тромплејских бића бивалентног онтолошког статуса. Реалност лудих и болесних наспрам реалности нормалних била је нова демаркациона линија.

Идеалан пример анализе оваквог типа границе налазимо у приповеци Bemap Лазе Лазаревића у којој јунака кроз лиминалне просторе (болница), границе живих-мртвих, води лекар. Ако бисмо Ван Генепову теорију

${ }^{5}$ Мучења којима је грофа Дракула подвргавао своје непријатеље и која су се захваљујући штампи брзо преносила, не само да су допринела стереотипизацији Балкана као опасне границе светова, већ су утицала на популаризацију садистичких прича. Твичел запажа да се у интерпретацијама занемаривала чињеница Цепешове одбране Запада од османских освајача jep је он постао „персонификација вампирског ужаса”. („The fact that Vlad Tepes was trying to protect his principality from encroachment from both East and West was overlooked, and he became the personification of vampire horror... There is no proof at all that he was a blood drinker, but even before Bram Stoker recreated him as the fictional vampire, „Dracula” was commonly believed to be such by middle Europeans" (Twitchell 1981: 17).

${ }^{6}$ У поменутом зборнику у студији Феномен балканских немртвих и њихова улога у културној пропаганди Мирела Холи (Mirela Holy) сумира разлоге зашто се Балкан сматра родним местом вампира: „Разлози томе су вишеструки. Као прво, поријекло ријечи вампир (опир) је старославенско, а сами назив вампир у западну је културу у раздобљу просвјетитељства вјеројатно ушао из српског језика након „вампирске епидемије” у 18. стољећу која је заустављена Вампирским указом царице Марије Терезије. Као друго, Стокер је у свом роману домовину Дракуле лоцирао на подручју Трансилваније, дакле на Балкану (...) Као треће, више повијесних докумената управо на подручју Балкана лоцирају вампире, а један од њих, први који је евидентиран у повијесним документима, јест истарски крвосис Јуре Грандо” (Холи 2019: 305).

${ }^{7}$ „Између здравог разума и лудила не постоји потпуна линија раздвајања, већ је то пре огромно и сеновито подручје" - Brewster 2001: 290; Шаровић 2008: 126). 
везану за обреде прелаза применили на болнице, онда бисмо у њима препознали лиминалне установе, места са „структурно недефинисаним” становницима (болесницима - и живима и мртвима или ни живима ни мртвима) и лекарима модерним супституентима врачева). ${ }^{8}$ Илустративна је анализа ове приповетке у студијама Снежане Милосаваљевић Милић („У мрежи испреплетаних времена - Хофман, Фројд и Лаза Лазаревић”; „Болест, слепило, потискивање - Ветар Лазе Лазаревића”) у којима се путања неодлучног јунака који улази у мистериозан простор болнице доживљава управо као симболички пример катабазе (силаска у подземни свет). ${ }^{9}$ Једна „овоземаљска путања” кроз болесничке ходнике и собе перспективирана из стања у којем је „путник” предвођен лекарем сагледава се као „топографија (два света, дугачак ходник као лиминални простор који спаја и раздваја)" у којем владају антитетички односи међу световима, опозиције: тамно-светло, свет „тишине” (Милосављевић Милић 2014: 5379, 81-93). Симболичкој префигурацији простора додајемо и (насловом истакнут) „ветар” који струји у наративном свету јунака али није метереолошка назнака; управо се јавља као знак необјашњивог алтернитета. Док је на примеру наше приповетке ветар интернализован кроз перцепцију јунака, у хришћанским атрибуцијама „ужасног”, „демонског”, „ђаволског” он се јавља екстернализован (Ди Нола, 2008). Пример те (тромплејске) екстернализације налазимо у балади Јована Суботића Сабља момче, ивет девојче ${ }^{10}$ или у опису југовине у Проклетој авлији Иве Андрића ${ }^{11}$.

${ }^{8}$ О овоме в. Вукићевић, Лазаревићев смех или смех у белом, у Лаза К. Лазаревић, живот и дело, 91-103); О лекарима водичима кроз катабазичко искуство видети и: Милосављевић Милић 2014: 53-77.

${ }^{9}$ „Читана у фигуративном кључу катабазичког наратива, приповетка „Ветар” би припадала традицији Орфејске катабазе - потраге за вољеном женом, која све време остаје нема. На трагу даљих аналогија уочавамо и рефлекс катабазе о Тезеју и Пејритоју: на јунаке приковане за столице заборава у хаду подсећа Јанко у посебном душевном стању када осећа да су му „доле за патос заковане ноге” (Милосављевић Милић 2009: 451).

${ }^{10}$ У духу старих хришћанских учења (најчешће апокрифних) зло се стани у самој природи - постоји као демонска сила мимо човека, која овладава њиме и која се може појавити у форми ветра. Код Јована Суботића у балади Сабља момче, ивет девојче јунак најављује долазак с оног света: „Подунуће виор ветар, / Прозор ће ти отворити/ Жижак ће ти угасити, / А ја ћу ти јавити се" (Суботић 1966: 123)

${ }^{11}$ На трагу хришћанских представа о нездравом, болесном, демонском ветру, Андрић описује дејство труле и опасне југовине „Хуји ветар и као невидљива болест пада по свима. И мирни људи се усплахире и почињу у неразумљивој раздражености да се љутити крећу тражећи кавге $[. .$.$] Живци се затежу до бола или нагло попуштају у опасним праскањима и безумним$ поступцима [...] У тим часовима општег узбуђења лудило, као зараза и хитар пламен, иде од собе до собе од човека до човека, и преноси се са људи на животиње и мртве ствари [...] тада изгледа да све што у Проклетој авлији има гласа урла и виче свом снагом, у болесној нади да 
Г) И док етнолошка и имаголошка литература мапирају лимитрофни простор, а психологија и медицина преиспитују перцептивну и менталну поузданост оних који су „прешли границу”, друга дисциплина, наратологија - поставља другачија питања везана за прелазак. Граница се овог пута посматра унутар саме приче и оног ко је прича, ко је слуша, коме се прича, коме се дешава... Ослањајући се на наратолошка проучавања: „неприродних" наратива (Alber, Heinze, Iversen, Mäkelä, Nielsen), онтолошких крајолика (Doležel, Pavel), привилегованих светова (Fludernik), питања : Како се раздвајају наративни светови? Ком свету се унутар приче даје статус привилегованог света? Како се компромитују или дезавуирају други светови? Који когнитивни оквири се активирају променом дијегезе? Како се одређује инстанца (не)поузданог приповедача, гаранта истинитости? ${ }^{12}$ скицирамо не с намером да у овом раду понудимо одговоре на њих већ да укажемо на другачијост приступа феномену границе. ${ }^{13}$

$$
* * *
$$

\section{Опште одлике тромплејских граница}

Прелазак границе између живих и мртвих, у тромплејским наративима увек је повезан са специфичним стањима путника и њиховим доживљајима простора: границе су испуњене страхом, амбивалентне су и флуидне.

би, негде на врхунцу ове буке, све ово могло попрскати и распасти се, и сврши на неки начин једном заувек (Андрић 1968: 37, 38).

${ }^{12}$ Не ретко се преко тромплејских јунака кроз супротстављене наративе испољава неодлучност и несигурност везана за њихов статус у свету приче (нпр. у „Документованом и детаљном саопштењу о вампирима..." наилазимо на пример супротстављених наратива који стварају недоумицу који изабрати за привилеговани (један се заснива на тумачењу вампира као персонификације одређених психичких стања, а други је заснован на поверењу у веродостојност искуствених сведочења). „Дакле узалудно је убеђивати се да све ово постоји само у машти живих људи, да су ови вампири можда умрли изненадном смрћу; да су можда рођаци сами били криви за смрт и да их зато мучи грижа савести. Изненадна смрт, међутим или грижа савести стварају код преосталих тугу, која изазива меланхолију која проузрокује немирне ноћи због чега слаби снага и болест на крају повлачи у смрт.” (в. Клеут 2018: 26) Недомицу додатно поспешује учесталост прича о појави вампира. Свако процењивање сведочења очевидаца као истинитих или лажних открива специфичности когнитивних оквира на основу којих се врши процена.

${ }^{13}$ В. студију Снежане Милосављевић Милић Мотив катабазе и наратолошки концепт света приче објаљену у монографији Кроз фикиионалне светове. Загробни свет се анализира према критеријуму аутентизације (Долежел 1998), алтеритета (Рајан 1991), онтолошке разлике (Павел 1986) и наративне екстензије (Херман 2002 ). 
Страх и зазор су пратећи елементи граничног тромплејског простора. Весна Марјановић (Представе о вампиру) пише да је страх био основа у свим облицима регулације друштва и да је фигурирао као моћно средство потчињавања, доприносио посебној димензији веровања у оностраност, у неприродне силе и у паралелене светове (Марјановић 2012: 12).

Друго својство које смо истакли у описивању тромплејског света, амбивалентност, такође се односи на разумевање простора. У тромплејској картографији locus horidus карактерише одсуство перцептивних сигнала уобичајених за чулно спознатљив свет. То је простор лишен физичких закона на којима почива разумевање односа: горе доле, лево-десно, испред-иза; може бити захваћен хтонским ветром, хладноћом, тмином, одсуством боје, одсуством мириса и сл. Будући да је тромплејски простор - простор непознатог, његова атрибуција се примарно врши кроз негације: то је некућа или не-гнездо. Описивање нечега што је непознато преко категорија познатог света - отвара простор за непрецизност, несигурност, амбивалентност, двосмисленост. Амбивалентност и Марија Шаровић издваја као битну одлику вампирског хронотопа: „Све одлике хронотопа у причама о вампирима засноване су на амбиваленцији бића које не припада ни једном ни другом свету. Зато оне увек оперишу са паровима опозиција које ту подвојеност треба да истакну: свет мртвих/свет живих (опозиције горе/доле, небески/земаљски свет, унутра/напољу, при чему категорија затвореног простора - куће, замка, воденице или цркве - не мора симболизовати сигурност и заштићеност, посебно у новијој књижевности)" (Шаровић 2009: 116)

Треће својство које издвајамо јесте флуидност, струјање кроз границу. У средишту смо парадокса, јер како ће да струји, прелази, пролази, онај ко је у једном свету, једној онтолошкој (идентитетској) димензији заустављен.

Суштина тромплејских јунака је да прелазе нереверзибилне границе у оба смера. Њихови су А) како вампирски путеви мртвих у свет живих, тако и Б) привремени путеви живих у свет мртвих.

За проучавање тромплејских путања јунака посебно су занимљиви наративи у којима се јављају јунаци у пару: живи посећују мртве, а мртви живе. Пут у непознато (у смеру од живих ка мртвима) отвара простор за нову фигуру, за пратиоца, водича. „На оваквом путовању, сигурно ће се на путу „наћи ријека и мост, море и чамац, дрво, спиља или провалија, пас и демонски или анђеоски водич душа или чувар прага - што су најчешће ознаке пута у земљу без повратка" (Eliade 1981: 58, Шаровић 2008: 115). Наративна комбинаторика се увећава не само укрштањем смерова кретања већ флуидношћу самих тромплејских јунака. То заправо значи да један тип тромплеја може апсорбовати особине другог и сл. 
За разумевање тромплејске путање јунака значајан је и начин њеног именовања (силазак, долазак, повратак). Свет умрлог може се пројектовати вертикално у односу на профани свет (као доњи простор у који се силази), или се, као у народној бајци, све дешава у једној хоризонталној равни, у којој се крећу и живи и мртви, између којих не постоји никаква нелагодност, чак је могући и физички контакт. (У бајкама, осим ове хоризонталне опције чешће се успоставља нека спацијална вертикала, па се мртви смештају у јаме или провалије.) Чињеница да је у бајкама степен апстракције толико велики да не постоји никаква нелагода у кретању између светова, упућује нас, у рецепцији наративних светова, на круцијалан значај жанра. У бајкама не постоји locus horidus jep за бајковите јунаке који живе у једном хомогеном свету (подједнако стварном и могућем) без обзира на његове различите пунктуме (доњи и горњи светови, чардаци ни на небу ни на земљи, баба Јагине кућице и сл.) ,феномен дуалитета јунака и наговештај лика двојника као слабе интрауниверзумске верзије" није уобичајен. ${ }^{14}$ Зато, иако се прелази граница, у бајкама она нема својства тромплејског простора. Locus horidus и наговештај лика двојника (као и расцепљене, уплашене јединке) уобичајенији је за демонолошка предања која су самим тим жанровски погоднији за „опстанак” тромплејских путника.

У којој мери жанр дефинише иреверзибилну границу између мртвих и живих сведочи различитост јунака који је прелазе - у хришћанској литератури приче о Христу, Лазару, свецима нису застрашујуће већ умирујуће. Христ је фигура синтезе, свеопште уједињености (православни теолог Оливије Клеман, аутор студије „Развој источног хришћанства”, пише о „изванредној синтези”, о ,једном бићу уједињених у Христу”). Све што би добило предзнак чудног, неприродног, зазорљивог - објашњено је, препокривено наративом о спасу душе и вечном блаженсту. За верујућег не постоји друга Другост осим оне која је „припитомљена” причом о Христу: „Јер где се установи устав човечје природе, да живи мртвима пишу, или да њима нешто говоре, или да мртви живе слушају, и заповести њихове врше? Али све ово чини реч господа мојега Исуса Христа: „Ко верује у мене, дела која ја чиним и он ће учинити, и већа од ових ће учинити." „Девојко, устани”; „Лазаре, изиђи ван” - рече Господ, и реч извршаваше.

${ }^{14}$ Анализирајући бајковиту организацију простора у приповеци Вечност, у којој се мртви и живи посећују, Снежана Милосављевић Милић објашњава природност кретања јунака у различитим световима: „Како су топографске и варијанте наративних јединки дате унутар једног заједничког референтног света текста, катабазички свет у овој народној приповеци није и алтернативни. Овакав статус светова, заправо, одговара генеричком типу бајке где нема „унутрашњег рецентрирања” - Rуan 1991: 34; Милосављевић Милић 2019: 451). 
Такође и многи од светих, по речи његовој, многа дела изнад природе човечјег устава у име његово учинише" (Теодосије, Житије Светог Саве, 71). Док у тромплејским наративима телесна бића остају ограничена својом биологијом и историјом, вером у Христа помера се егоистично, пропадљиво, материјално (телесно) ја из сопствене историје у сферу вечног, рајског и блаженог. Житије Светог Саве завршава се молитвом за опрост грехова чиме се трансцендира смрт и улази у дубљу метафизичку димензију постојања у Богу.

Потпуно је другачија бит тромплејских јунака. Они су фигура раздвајања, никада синтезе; то су зазорљива бића. У стварном свету ужасна искуства смрти која се не могу превести у разумљивост говора архивирају описи дехуманизованих, немогућих а постојећих простора: „Живот у концентрационом логору не може се поредити ни са чим. Његове ужасе машта никада не може до краја да појми, зато што се налазе с ону страну живота и смрти" (Арент 1998: 451). Хана Арент пише о ужасу логорашког живота-смрти, о терору који води ка самозабораву и самоукидању: „У концентрационим логорима и логорима смрти затвореницу су, чак и ако успеју да се одрже у животу много ефикасније одсечени од света живих него да су заиста умрли, зато што терор појачава заборав и у томе је сав њихов ужас” (Арент 1998: 450). Логорашке „преживеле” дечије ципелице које нема ко више да обува и у књизи Моћи ужаса. Огледи о зазорности пример су неподношљивог осећања зазорљивог.

У поређењу с искуством зазорљивог реалног света, фикцијски тромплејски свет се не обрађује кроз знање и памћење које трансцендирају неподношљиво „никад више” искуство субјекта. Тромплејска реалност се обликује с оне стране језика, а ако следимо Витгенштајнову идеју да су границе нашег језика границе нашег света, онда је тромплејски искорак увек повезана са прекидом, неповратом у континуитет ранијег бивствовања; сваки прекид је једна врста смрти; тромплејско биће искушавано смрћу је несавладиво маштом и недосегнуто речју. Оно није опомена јер се не може кроз опомену спознати, нити се њииме из ретроспективне позиције причања може говором овладати, оно је граница приче, њена немост и искорак у не-постојаност. Вампир је његово нагађање увек с ове стране приче и с ове стране говора. 


\section{ЛИТЕРАТУРА}

Arent Hana 1998: Izvori totalitarizma, Beograd: Feministička izdavačka kuća 94.

Bandić Dušan 1990: Vampir u religijskim shvatanjima jugoslovenskih naroda, Beograd : I. Čolović : D. Bandić : I. Mesner, str. 61-92, 103-120.

Bandić Dušan 1990: Posmrtno umiranje u religiji Srba, Carstvo zemaljsko i carstvo nebesko, Beograd : I. Čolović : D. Bandić : I. Mesner, str. 103-120.

Вукићевић Драгана 2012: Лазаревићев смех или смех у белом, у Лаза К. Лазаревић, живот и дело, Српско лекарско друштво Београд, 91-103.

Делимо Жак 1989: Страх на Западу, Нови Сад: Књижевна заједница Новог Сада.

Ди Нола Алфонсо М. 2008: Đavo, Beograd : Clio.

Ђорђевић Тихомир 1953: Вампир и друга бића у народном веровағу u предањy, Српски етнографски зборник 66, Београд.

Eliade Mircea 1981: Okultizam, magija i pomodne kulture, Zagreb: Grafički zavod Hrvatske. Crawford, Marion, F., For the Blood is Life, http:// www.litgothic.com/Texts/for-theblood-is-life.html.

Клеут Марија 2018: Вампири у Србији у 18. веку, књига и коментари, Београд: Службени гласник.

Крв: култура књижевност 2016, Посебна издања 134. Балканолошки институт Српске академије наука и уметности.

Kristeva Julia 1989: Moći užasa: ogled o zazornosti, Zagreb: Naprijed.

Лазаревић ди Ђакомо Персида 2016: ,, У юеговим устима се видело нешто свеже крви”. Разлози указа Царице Марије Терезије о вампиризму, y: Крв, књижевност, култура, Београд : Балканолошки институт САНУ, 129-150.

Liber monstrorum balcanorum - чудовишни свијет еуропске маргине 2019, Загреб: Jesenski i Turk i Institut za etnologiju i folkloristiku.

Марјановић В., Стојиљковић Д. 2012: Живи покојник, Београд: Службени гласник,

Milosavljević Milić Snežana 2019: Motiv katabaze i naratološki koncept sveta priče. / U: WIELKIE TEMATY KULTURY W LITERATURACH SŁOWIAŃSKICH 13, Tanatos 2, SLAVICA WRATISLAVIENSIA CLXVIII (Red. Elžbieta Tyszkowska-Kasprzak, WspÔlpraca Gordana Đurđev-Malkiewicz, Mateusz Šwietlicki, Dorota Žygadło-Czopnik), Wydawnictwo Uniwersytetu Wroclawskiego, Wroclaw, 2019, str. 451-459.

Милосаваљевић Милић Снежана 2014: У мрежи испреплетаних времена - Хофман, Фројд и Лаза Лазаревић, у: Вукићевић Драгана, 
Милосаваљевић Милић Снежана, Огледавања : Лаза Лазаревић - Симо Матавуљ, Ниш : Филозофски факултет.

Милосаваљевић Милић Снежана 2014: Болест, слепило, потискивање - Ветар Лазе Лазаревића у: Вукићевић Драгана, Милосаваљевић Милић Снежана, Огледавања : Лаза Лазаревић - Симо Матавуљ, Ниш : Филозофски факултет, 2014.

Hapauиja cmpaxa, 2019: Leykam International d.o.o. i Institut za etnologiju i folkloristiku

Павел Томас 1997: Фикционални светови и еконимија имагинарног, Реч, 30, 111.

Ана Радин 1996: Мотив вампира у миту и књижевности, Београд: Просвета.

Суботић Јован 1966: Сабља-момче, ивет-девојче, у Антологија старије српске поезије, прир. М. Лесковац, Нови Сад: Матица српска, 122-135.

Теодосије, Житије Светог Саве, http://www.antologijasrpskeknjizevnosti. rs/ASK_SR_AzbucnikDela.aspx

Twitchell James B.: The Living Dead A Study of the Vampire in Romantic Literature, Duke University Press Durham, N.C. 1981.

Холи Мирела 2019: Mirela Holy, Fenomen balkanskih nemrtvih i njihova uloga u kulturnoj propagandi y: Naracija straha, Leykam International d.o.o. i Institut za etnologiju i folkloristiku.

Чајкановић Веселин 1994: Стара српска религија и митологија, Сабрана дела из српске религије и митологије, књига пета (Војислав Ђурић, прир.), Београд: СКЗ - БИГЗ - Партенон.

Чајкановић Веселин 1994: Студије из српске религије и фолклора 1910 - 1924, Сабрана дела из српске религије и митологије, књига прва (Војислав Ђурић, прир.), Београд: СКЗ - БИГЗ - Партенон.

Шаровић Марија 2016: Крв у наративима и представма о вампиpима, у: Крв, књижевност, култура, Београд : Балканолошки институт САНУ, 287-300.

Шаровић Марија 2009: Типови хронотопа у прози о вампирима, Моћ књижевности, in memoriam Ана Радин, Београд: Балканолошки институт, $113-134$.

Шаровић Марија 2008: Метаморфозе вампира: компаративна анализа мотивског комплекса вампира у делима Р. Метисона, Б. Пекића, Б. Вијана и С. Лујањенка, Београд : Институт за књижевност и уметност. 
Dragana B. Vukićević

\section{BOUNDARY: THE LIVING DEAD}

\section{Summary}

The paper studies different ways of conceptualization the irreversible boundary between the world of the living and the world of the dead. It is a segment of a broader study of trompe l'oeil beings, those who are ontologically bivalent, and untranslatable into the world of possible experiences and speech.

Key words: vampire, boundary, rite of passage, narrative, tromple l'oeil beings. 